\title{
Molecular basis of transient neonatal diabetes mellitus in Japan: frequent KATP-TNDM and identification of a patient with a monoallelic INS mutation
}

Tohru Yorifuji 1,2,3* , Yuki Hosokawa', Rie Kawakita', Yukiko Hashimoto ${ }^{1}$, Azumi Sakakibara', Rika Fujimaru' Nobuyoshi Tamagawa ${ }^{2,3}$

From 8th APPES Biennial Scientific Meeting

Darwin, Australia. 29 October - 1 November 2014

\section{Background}

It has been reported that the most common $(\sim 70 \%)$ form of transient neonatal diabetes mellitus (TNDM) is 6q24-related TNDM, followed by TNDM caused by activating mutations in the KATP channel genes (KCNJ11 and ABCC8, KATP-TNDM) which accounts for approximately $30 \%$ of TNDM. Recessive promoter mutations in the insulin (INS) gene also have been reported as rare causes of TNDM.

\section{Aims}

To elucidate the molecular basis of TNDM in Japan.

\section{Methods}

Nineteen Japanese patients with TNDM were analysed by methylation specific PCR of the differentially methylated region at chromosome 6q24 and by PCR amplification and direct sequencing of all exons and exon-intron boundaries of the KCNJ11, ABCC8, and INS genes.

\section{Results}

6q24 abnormalities were identified in 7 (paternal duplication in 4, paternal uniparental disomy or epimutation in 3), mutations of ABCC8 (R1380C, R216C, V607M) in 3, KCNJ11 (E227K, R50Q, C42R) in 3, and INS (Q62X) in 1.

\section{Conclusion}

As compared with previous reports, the frequency of KATP channel mutations were higher in this Japanese

'Department of Pediatric Endocrinology and Metabolism, Children's Medical Center, Osaka City General Hospital, Japan

Full list of author information is available at the end of the article cohort. In addition, this is the first report of a monoallelic, coding sequence mutation in the INS gene (Q62X) responsible for TNDM.

\section{Authors' details}

'Department of Pediatric Endocrinology and Metabolism, Children's Medica Center, Osaka City General Hospital, Japan. ²Department of Genetic Medicine, Osaka City General Hospital, Japan. ${ }^{3}$ Clinical Research Center, Osaka City General Hospital, Japan.

Published: 28 April 2015

doi:10.1186/1687-9856-2015-S1-O32

Cite this article as: Yorifuji et al:: Molecular basis of transient neonatal diabetes mellitus in Japan: frequent KATP-TNDM and identification of a patient with a monoallelic INS mutation. International Journal of Pediatric Endocrinology 2015 2015(Suppl 1):032.

Submit your next manuscript to BioMed Central and take full advantage of:

- Convenient online submission

- Thorough peer review

- No space constraints or color figure charges

- Immediate publication on acceptance

- Inclusion in PubMed, CAS, Scopus and Google Scholar

- Research which is freely available for redistribution

Submit your manuscript at www.biomedcentral.com/submit 